\title{
Just war theory after colonialism and the war on terror: reexamining non-combatant immunity
}

\author{
Gabriel Mares \\ Department of Political Science, UMass-Amherst, 200 Hicks Way, Amherst, MA, USA \\ Corresponding author. E-mail: gmares@polsci.umass.edu
}

(Received 8 January 2019; revised 1 January 2020; accepted 10 August 2020;

first published online 7 October 2020)

\begin{abstract}
I challenge a recent trend in just war theory - that civilians might be complicit with terrorists and lose non-combatant immunity - by reversing the gun sights and asking whether colonizing populations complicit with empire might compromise their non-combatant status. Employing colonial settlers as a thought experiment, I demonstrate the logic of expanded civilian culpability that has been proposed in the wake of the War on Terror would be unacceptable in other scenarios, and that these revisionist proposals are in service of ends incompatible with just war. In the process, I identify an important ambiguity regarding the performativity of non-combatant status, and show how this is used to aggressively expand civilian culpability for violence.
\end{abstract}

Keywords: civilians; just war theory; liability; non-combatant immunity; postcolonialism

The War on Terror generated and invigorated intense debates about the boundaries of combatant and non-combatant status. While international humanitarian law (IHL) and just war theory both account for ways in which civilians might surrender their immunity in wartime, a new wave of scholarship proposes that a much greater portion of civilian populations are responsible for or complicit with terrorist violence, and thus either do not merit civilian immunity or their immunity can be overridden more easily. ${ }^{1}$ Furthermore, some US military practices in Iraq and drone targeting in particular appear to embrace this suspicion of foreign civilians.

\footnotetext{
${ }^{1}$ Most prominently, Michael L. Gross Moral Dilemmas of Modern War (Cambridge 2010) and Asa Kasher and Amos Yadlin, 'Military Ethics in Fighting Terror: An Israeli Perspective', in Journal of Military Ethics 4 (1): 3-32, 2005. Other examples I engage include Tamar Meisels The Trouble with Terror (Cambridge 2008), and Eric Jensen, 'Direct Participation in Hostilities: A Concept Broad Enough for Today's Targeting Decisions' in Davis, ed. New Battlefields/Old Laws.

(c) The Author(s), 2020. Published by Cambridge University Press. This is an Open Access article, distributed under the terms of the Creative Commons Attribution-NonCommercial-ShareAlike licence (http://creativecommons.org/licenses/ by-nc-sa/4.0/), which permits non-commercial re-use, distribution, and reproduction in any medium, provided the same Creative Commons licence is included and the original work is properly cited. The written permission of Cambridge University Press must be obtained for commercial re-use.
} 
A simple response to these innovations would be to reassert the importance of broad civilian immunity based on human rights, empathy, or international law. ${ }^{2}$ This essay, by contrast, takes the logic of broadened conceptions of direct participation in hostilities and narrowed civilian immunity at face value and asks whether traditional understandings of direct participation in hostilities obscure ways in which civilians may be party to repression and violence. This question can be examined in a novel way by focusing on colonial situations, in which settlers both demand violence against indigenous populations and engage in systematic expropriation and denial of rights and sovereignty to others. Such a reframing allows us to explore and critique the logic driving recent critical reassessments of civilian complicity, but with the gun sights metaphorically reversed: asking whether the citizens of Western, colonial states might be justly targeted. It is easier to theorize that others may not have the right to traditional protections than to question whether 'we' might not merit those protections. In addition to challenging the logic employed by Gross (2010) and others, this postcolonial reversal illuminates two additional problems surrounding non-combatant immunity. There is an unacknowledged ambiguity as to whether the combatant/non-combatant distinction in just war theory is based on performative roles or inherent identities. ${ }^{3}$ In addition, many of the recent critical reassessments of civilian immunity are in service of (often punitive) ends which are ultimately incompatible with both just war theory and IHL.

Reframing the question of immunity around the colonial context can be used not only in refuting the logic of theorists like Gross, Jensen, Meisels, and others, but in changing the questions we ask about contemporary conflict, especially surrounding occupations, terrorism, and insurgencies. By exploring a narrow theoretical possibility for justly targeting those who actively participate in permanent occupations and the denial of sovereignty, I determine that the demands and complications of the real world, specifically the perils of reliable distinguishability, effectively eliminate this possibility and that attempts to overcome the problem of non-combatant distinguishability result in targeted killing or punishment, rather than direct targeting. ${ }^{4}$ Because punishment and targeted killing are not traditionally considered legitimate ends in just war, I argue that this means attacking such targets would be unjust and they must be dealt with through other means.

The theoretical argument in this essay focuses on indigenous populations that directly target settler colonists as part of a rebellion in order to establish their own political authority. ${ }^{5}$ This essay is divided into five sections. The first section introduces the relevance of postcolonial critique to ethics in war. The second

\footnotetext{
${ }^{2}$ This sort of broad reassertion of civilian innocence is found in Seth Lazar's (2015) response to leading 'revisionist' accounts of just war theory.

${ }^{3}$ This problem is addressed historically in Kinsella with reference to the constitutive part that gender roles - not simply the identity of womanhood - played in understandings of how immunity was constituted in early Church writings (Kinsella 2012, 31).

${ }^{4}$ Questions of jus ad bellum and right authority are beyond the scope of this essay: for present purposes, I am working on the assumption that at least some anti-colonial resistances would meet these standards.

${ }^{5}$ Settlers that come from the mother country that fight to secede and establish their own nation in which they subordinate or do not respect the rights of indigenous populations remain in the category of aggressors against the territorial integrity and political sovereignty of the indigenous population, for example Rhodesia
} 
section presents an overview of recent work that seeks to limit eligibility for noncombatant immunity because of supposed complicity with terrorists and terrorist organizations. The third examines the construction of non-combatant immunity in both just war theory and IHL, and explores an ambiguity regarding role and identity that plagues the determination of combatant status in both traditions. The fourth section presents the theoretical challenge of reassessing the validity of traditional just war categories in the colonial context. Here an argument is advanced that challenges the assumption that colonial settlers, because they do not bear arms, are not directly participating in hostilities. The theoretical exploration allows a richer interaction between political history and just war theory by de-centering the European nation-state as the grounds for theorizing ethics and war, and critically engaging the logic of expanded civilian complicity. The fifth section asks: would it be possible to justly target settler colonists under revised logics of just war theory and IHL? This inquiry proceeds by examining the role of the settler in a colonial system's territorial aggression. Through this, I explore a narrow theoretical possibility for a just form of settler targeting. However, I demonstrate that this form of targeting is made impossible by the real world consideration of distinguishability. I use this conclusion to argue against attempts to narrow civilian immunity since the War on Terror.

\section{The enduring relevance of the colonial}

Settlers in a colonial context are a helpful analogy for re-examining civilian immunity because of the ways in which their participation in the colonial project - even when not carrying out violence themselves - were simultaneously an integral part of and justification for domination. Today, membership or affiliation, indirect participation, responsibility, guilt, and expansive understandings of collateral damage have all been cited to justify killing civilians when attacking terrorist targets. But these same justifications can also be recognized in the colonial context.

While the importance of colonial concepts might seem to have abated because of the dearth of classic colonial situations in the modern world, ${ }^{6}$ they continue to exert a strong influence on the world. Concepts pioneered after the end of formal colonialism may be guided by a strong colonial logic if they were developed with reference to the colonial world. A central aim of postcolonial scholarship is to illuminate and challenge these concepts. ${ }^{7}$ Within just war theory, critiques of anti-colonial violence are the basis of a broader critique of terrorism, ${ }^{8}$ arguing that such violence could never be justified because it intentionally attacked noncombatants. Thus, the colonial looms large in just war concept formation.

When discussing terrorism in the Algerian war for independence, Michael Walzer invokes a scene from the film 'The Battle of Algiers' in which a cafe

and apartheid South Africa. Their secession experience is distinct from an indigenous population's fight for independence and will not be considered here.

${ }^{6}$ In this paper I do not consider territorial disputes in which two parties have historical-cultural claims to territory to be Modern colonial contexts. In particular, the cases of Kosovo and Israel-Palestine have too many overlapping claims to treat thoroughly here.

${ }^{7}$ E.g. Mamdani 1996, Anghie 2005.

${ }^{8}$ Walzer 2000, Elshtain 2007, Johnson 1999. 
frequented by French Algerians is bombed by Algerian rebels. He uses this to highlight the indiscriminate character of targeting by the FLN - civilians out and about are targeted not because of any threat they pose, but rather for who they supposedly are. ${ }^{9}$ Perhaps Walzer is right. To illustrate the theoretical exploration this article pursues, consider another scene from the film: a military parade down the streets of the French part of the city, with colonial citizens cheering the arrival of the French paratroopers - whose task is to crush the Algerian uprising.

Would it be legitimate for insurgent forces to bomb such a rally? Employing the logic of broadened direct participation in hostilities, I question whether both the men-in-arms and those there to cheer them might be legitimate targets. While civilians at political rallies would be immune from attack, are these settlers instead directly supporting violence? They are not only openly showing support for the deployment of the forces of the state to crush an indigenous insurgency, but for the violent continuation of a 130-year old oppression of which they are a part. In this scenario the civilians are not innocent qua blameless and, more importantly, they are participating in the occupation of territory. Should these factors cause us to reconsider their status as non-combatants? And if not, how does that judgment expose problems with other recent attempts to narrow the concept of non-combatant?

A postcolonial perspective draws more attention to agents and structures of empire, rather than treating empire as of secondary importance compared to the metropole. In this essay, I treat settler colonialism as a normal political phenomenon rather than as a rare exception. Settler colonialism is a system 'defined by unequal relationships (like colonialism) where an exogenous collective aims to locally and permanently replace indigenous ones (unlike colonialism)'. Individuals are settler colonists 'if they are part of a collective and sovereign displacement that moves to stay, that moves to establish a permanent homeland by way of displacement'. ${ }^{10}$ Although James Sterba (2002) and Jeff McMahan (2010) examine the possibility of targeting settlers in the contemporary Israeli case, they frame settlers as possible exceptions to a broad norm of civilian immunity. In treating settlers as exceptions, neither examines how the structural violence of the settler goes unexamined in just war. In this essay I set aside the question of contemporary Israeli settlers and instead recognize the colonial settler as normal rather than exceptional in the history of European colonialism. I argue that treating settlers as normal reveals tensions and ambiguities in the tradition's idea of non-combatant status.

Some major just war theorists ${ }^{11}$ championed wars of imperial ambition and recent attempts to narrow civilian immunity largely affect non-Western peoples. Might just war be re-purposed in this millennium to challenge moralizing approaches to dehumanization and postcolonial domination? To embark on such a political path, I demonstrate that a postcolonial critique of just war can be productive theoretically. Rather than offering yet another rejection of the tradition, I use my internal critique of just war to challenge empire's new champions.

\footnotetext{
${ }^{9}$ Walzer 2000, 205.

${ }^{10}$ Veracini 4, 2016.

${ }^{11}$ Elshtain 2004, Tesón 2005, Johnson 2005, Walzer 2006.
} 


\section{Eroding non-combatant immunity}

In conjunction with the War on Terror, there are a series of efforts to narrow eligibility for civilian immunity. Michael Gross proposes eliminating the dichotomy of direct participation/non-participation in order to introduce graduated levels of civilian participation that may justify differing levels of direct targeting, as well as non-lethal attacks against 'associated targets', which would include civilian institutions such as banks and schools. ${ }^{12}$ Others propose that direct participation may be defined as encompassing all members of hostile non-state groups, regardless of individual actions - treating membership in such a group as akin to the status of unlawful combatant, that is, legitimate targets without any protections, privileges, or immunities that soldiers receive. ${ }^{13}$ Jensen and Gross's positions in particular reveal a desire to differentiate among civilians, rather than treating civilians as a class. Tamar Miesels argues for treating 'terrorist masterminds' as targets thus permitting a level of collateral civilian death similar to targeting a munitions factory, thus eliding the difference between a mobile person and a stationary building. ${ }^{14}$ Asa Kasher and Amos Yadlin hold that civilian immunity for populations that (broadly defined) support terrorists necessarily must be weaker, and that a state may prioritize protecting their own combatants at the cost of the other side's civilians in such scenarios. ${ }^{15}$ Amitai Etzioni goes further, bypassing academic audiences and engaging the public through op-eds, articulating a moral defense of 'flattening' civilian neighborhoods and cities with advanced aerial weaponry in order to destroy suspected stockpiles of terrorists' weapons. ${ }^{16}$

Expanded understandings of participation and minimized notions of civilian immunity are also present in recent US military operations. In Iraq, civilians not immediately responding to ambiguous and arbitrary signals when approaching makeshift roadblocks were immediately classified as threats that had to be neutralized. ${ }^{17}$ In drone warfare, 'signature strikes target anonymous suspected militants... which "in effect counts all military-age males in a strike zone as combatants... unless there is explicit intelligence posthumously proving them innocent"'. ${ }^{18}$ In both cases, foreign bodies themselves are presumed to be violent and threatening in the absence of direct evidence of innocence - the inverse of just war's traditional approach to legitimate targeting. The Joint Chiefs of Staff have gone so far as to declare that 'hostile acts and hostile intent may not be required in some instances...Any civilian, paramilitary, or military force or terrorist(s)...that has committed a hostile act, exhibited hostile intent, or has been declared hostile by appropriate US authority' may be targeted. ${ }^{19}$

The main thrust of attempts to narrow civilian immunity and expand definitions of direct participation is directed primarily against civilian collaboration with terrorists and resistance fighters. A few scholars have taken the War on Terror as

\footnotetext{
${ }^{12}$ Gross 2010.

${ }^{13}$ Jensen 2011.

${ }^{14}$ Meisels 2008.

${ }^{15}$ Kasher and Yadlin 2005.

${ }^{16}$ Etzioni 2016.

${ }^{17}$ O'Callaghan 2015, 116.

${ }^{18}$ Zenko 2013, 12.

${ }^{19}$ Cited in Crawford 2013.
} 
an opportunity to challenge the immunity of democratic publics that authorize (through elections) aggression against other states and people. Igor Primoratz (2002) addresses this theoretically by reframing the classification of 'innocent' as a moral judgment of blamelessness, rather than an assessment of harmlessness which might ultimately legitimate targeting as a punitive practice.

Another important recent attempt to expand civilian liability is Michael Gross' (2015) argument that civilian participation is more like a sliding scale than a binary choice, thus the treatment of enemy civilians should also be on a sliding scale. Here he uses the ICRC's category of 'indirect participation' to promote non-lethal forms of targeting, which might include detention, disabling financial institutions, and attacking civilian infrastructure and other 'associated targets'. This builds on his earlier work (2010) but in applying it to guerrilla warfare rather than counter-terror and COIN he argues that an absolute prohibition on targeting civilians and their infrastructure denies 'just' guerrillas a fighting chance. The forms of 'indirect participation' he believes make one (non-fatally) liable to attack are traditionally understood - deliveries, logistics, anyone 'drawing a paycheck' related to the hostilities, as it were. ${ }^{20}$ By contrast, this essay examines whether structural forms of oppression, namely settler colonialism, might expand our understanding of 'direct participation' - rendering its participants liable to lethal targeting.

\section{Civilian immunity in just war theory and international humanitarian law}

The principle of civilian immunity is central to modern laws and ethics of war. Often interchangeably referred to as civilians, non-combatants, or innocents, they are understood to be immune from direct targeting in war. There are concrete ways in which this class of people forfeit their immunity - Michael Walzer argues that combatants are defined as people who 'effectively bear arms', while Additional Protocol 1 (1977) to the Geneva Conventions defines the loss of civilian immunity as due to 'direct participation in hostilities'. These two views do not overlap perfectly, but at a basic level both implicate those who threaten violence while maintaining a broad understanding of who should not be targeted.

The terminology for different ways of killing civilians in conflict zones is important. The primary distinction is between direct targeting and collateral death. The direct targeting of civilians who are not directly participating in hostilities is unjust, while the collateral death of such civilians may be just. If a civilian becomes a direct participant in hostilities, she is directly targeted by an opposing force not as an individual who should be punished (although she may be liable to prosecution if she is an unlawful combatant), but as a direct threat. Two forms of unjust direct targeting of civilians are punishment (the retributive killing of civilians) and the instrumental killing of civilians (killing civilians in order to weaken an enemy's morale or ability to fight). Direct targeting is also different than targeted killing, a neologism describing assassination, in which targets are selected on information gathered in advance, rather than reacting to observing direct participation in hostilities. ${ }^{21}$ These terms are not necessarily mutually exclusive - in the real world,

\footnotetext{
${ }^{20}$ Gross 2015, 74.

${ }^{21}$ Gross 2015, 74.
} 
some overlap is common. It is important, however, to clarify and isolate the intervention this essay makes: the argument advanced herein is about direct targeting, and questions solely about collateral death, targeted killing, and punishment are beyond the scope of the argument.

It is important to engage just war and IHL simultaneously. Treating law as legitimate without reference to an outside ethical judgment can result in uncritical analysis of compliance that simply affirms whatever assumptions, interests, or prejudices may have guided the drafting and ratification of law. ${ }^{22}$ Just war is a philosophical, juridical, and theological tradition which does not always agree with IHL in its principles or conclusions, although they have a reciprocal relationship - just war theory influenced sources of IHL, and just war theorists now regularly cite IHL. ${ }^{23}$ Evaluating non-combatant immunity simultaneously through just war and IHL may prevent a study from falling into empty formalism.

To update the just war tradition, Walzer draws on Articles 2(4) and 51 of the UN Charter as well as the 1974 General Assembly definition of aggression in order to argue that the primary crime in the international sphere is the crime of aggression. 'Every violation of the territorial integrity or political sovereignty of an independent state is called aggression'. ${ }^{24}$ The most recognizable form of aggression is military invasion. Thus, according to just war theory, a war to expel aggressors (a war of self-defense) is automatically just. Whether it is fought in a just manner, however, is a different question.

The principle of discrimination is the codification of the idea that there are legitimate and illegitimate targets. Armed forces must discriminate between directly attacking military targets and civilians. By embracing a distinction between who may and who may not be attacked, just war theory argues that the realities of war do not preclude, but in fact mandate, moral decisions. People 'have a moral standing independent of and resistant to the exigencies of war...Combatants give up their right not to be harmed by themselves threatening harm; non-combatants are people who have not done so and thus still possess that right'. ${ }^{25}$

When defining the combatant/non-combatant distinction in Just and Unjust Wars, Walzer speaks of soldiers as a 'class' that is vulnerable to attack because of the threat of violence this class presents. Non-combatant, though, is presented as both an identity as well as a role - he writes that 'civilians' have not given up their non-combatant status because they have not done anything to lose it, by which he means they have not engaged in violence. If a 'civilian' picks up the gun of a dead soldier that had been defending a town and shoots at attacking soldiers, he is still not a formal 'solider' -however, the civilian has become a 'combatant' and may be justly killed by the attacking soldiers.

Consequently, the categories of combatant and non-combatant are not as easily defined as a simple soldier/civilian dichotomy. Jean Elshtain notes that, 'the presumption against violence frames just war thinking and must always be brought

\footnotetext{
${ }^{22}$ Dill 2015, 11.

${ }^{23}$ Orend 2006, 4.

${ }^{24}$ Walzer 2000, 52.

${ }^{25}$ Johnson 1999, 131.
} 
to bear when considering the resort to force' ${ }^{26}$ Thus, to reduce killing in war, just war theory focuses on the actions of individuals, rather than on their basic identities. Non-combatant immunity is lost (in Walzer's formulation) when someone 'effectively' bears arms in a theater of war. Not all soldiers in a theater of war effectively bear arms. It is immoral to kill wounded or surrendering enemy soldiers because they do not threaten violence as does a soldier who effectively bears arms. A soldier in a theater of war able to bear arms effectively is a combatant; outside of a theater of war he is a non-combatant. Momentary lapses in attention while in a theater of war do not reclassify the soldier as no longer effectively bearing arms - such distractions do not prevent soldiers from threatening violence. The same logic, however, does not apply to people outside of that class - a bathing soldier is targetable because he could instantly threaten harm, a bathing civilian is not targetable even though, conceivably, he could also engage in violence after this lapse in attention. But since civilians are not part of the class of soldiers, they can only be targeted if they are actively threatening violence. Soldier as a class, then, implies a role which makes considerations of targeting different than for people outside of that class. Class, it bears repeating, is not reducible to identity because the identity of the soldier does not in and of itself pose a threat to others.

Non-combatant immunity is not an absolute protection; the doctrine of double effect (collateral death) permits the killing of civilians if they are not the targets of the attack, if care has been taken to minimize the number of civilian casualties, and if the estimated number of civilian casualties is not 'excessive in relation to the concrete and direct military advantage anticipated'. Thus, workers in a tank factory are not unjustly killed if the factory (a legitimate strategic objective) is bombed, although the attacker should ideally bomb the factory when the fewest workers are inside. It would be unjust to strafe these workers on their way home - they are assisting in the military effort by working in the tank factory, but outside of the factory they are not engaged in the war, and thus immune from attack.

The immunity of non-combatants is better understood as immunity from direct targeting, not simply from being attacked. Again, a civilian's identity and her role may differ in a combat zone. Civilians are united in that they may not be targeted however, they may be killed (collaterally) when the roles they fulfill in society are exclusively helping the violence carried on by soldiers (such as working in a tank factory). This excludes roles that are necessary to all forms of living - farmers may provide food for soldiers, thus aiding the war effort, but the act of farming is not exclusively related to the war. ${ }^{27}$

Thus, by the doctrine of double effect, a distinction between simply 'attacking' and specifically 'targeting' is created. This distinction is very important, and the doctrine of double effect is essential to waging war - while armies should take care to significantly minimize civilian casualties, inevitably some will occur. It would be impossible to wage an effective military campaign while honoring a promise of zero civilian casualties. However, because of just war theory's presumption against killing, positive efforts must be made to ensure as few civilian lives as possible are lost. One could not aerially target a checkpoint continuously manned

\footnotetext{
${ }^{26}$ Elshtain 2004, 223.

${ }^{27}$ Walzer 2000, 146.
} 
by a small cadre of soldiers if it were located next to an orphanage - while the soldiers would be legitimate targets, such a bombardment would unnecessarily risk the lives of scores of children. It would be the attacker's positive responsibility to search for ways of circumventing the checkpoint, or otherwise diminishing its importance as a strategic objective. Thus, even if an important strategic target a 'terrorist mastermind' as Meisels (2008) suggests - were passing through that checkpoint, to attack the target at that location would be to almost certainly recklessly endanger an unjustifiable number of non-combatants, meaning that the target would have to be engaged at another location. To posit that a critically important moving target could only be engaged at one particular location, thus any collateral damage would be justifiable, is simply a re-framing of the 'ticking time bomb' hypothetical with all its attendant assumptions and problems. ${ }^{28}$

The standards in international law are different. The definition of civilian was not, until recently, a central concern of IHL. At the Hague Conventions, much of the legal question was determining who was a lawful combatant, rather than who was a civilian. ${ }^{29}$ Similarly, much of the postcolonial legal question (such as the recognition of CAR conflicts through UN General Assembly Resolution 3103 in 1973) has been expanding right authority, not re-thinking civilian-ness. A major source of civilian immunity in IHL is Additional Protocol 1 of the Geneva Convention (1977), Article 51(3), which states: 'Civilians shall enjoy the protection afforded by this Section, unless and for such time as they take a direct part in hostilities. ${ }^{30}$ Commentators note that 'the adjective "direct" does not shed much light on the extent of participation required. ${ }^{31}$ The ICRC issued an Interpretive Guidance, although it is non-binding, to clarify the meaning of 'direct participation' through three characteristics: a specific act must (1) 'adversely affect' or kill, injure, or destroy either legitimate or illegitimate targets, (2) have 'a direct causal link between the act and the harm likely to result either from that act, or from a coordinated military operation of which that act constitutes an integral part', and (3) must support one side of the conflict against another side of the conflict (i.e. must be relevant to the conflict - thus, private violence unrelated to the conflict would not constitute direct participation in hostilities). ${ }^{32}$ It is vital that 'the concept of direct participation extends beyond those who bear arms $^{33}$ - although the guidelines require the harm be caused in one causal step, it is possible that the specific act itself extends it beyond 'effectively bearing arms', which is the standard Walzer proposes.

By focusing on 'direct participation in hostilities' IHL is much more attuned to the problems of performative roles. However, because the ICRC's Interpretive Guidance is not binding and the role of the ICRC as chief interpreter is contested, different interpreters of international law bring the role-identity ambiguity back in.

\footnotetext{
${ }^{28}$ See David Luban, 'Unthinking the Ticking Bomb' (2008). Georgetown Law Faculty Working Papers. Paper 68. http://scholarship.law.georgetown.edu/fwps_papers/68.

${ }^{29}$ Nablusi 1999.

${ }^{30}$ International Committee of the Red Cross (ICRC) 1977.

${ }^{31}$ Dinstein 2004, 27.

${ }^{32}$ Akande 2010, 187.

${ }^{33}$ Akande 2010, 181.
} 
The classic example of the munitions factory worker ${ }^{34}$ presents new problems in this light - the worker is assumed to be a generic industrial laborer, one whose participation in hostilities or culpability for violence extends only as far as the workday ('and for such time as they take a direct part in hostilities') - outside of the factory, she is not a threat. She is assumed not to be a munitions expert, but that her work is essentially interchangeable with other factory work. Not so of the 'terrorist bombmaker', who - according to Jensen, Meisels, Gross, among others - is directly participating in hostilities regardless of whether she is in her workshop or not, and thus may be targeted at any time or place and, because of the international scope of the War on Terror, is unable to ever leave the theater of war. ${ }^{35}$ Comparing the munitions factory worker and the terrorist bombmaker, we may say the former is theorized as performing her role, while the latter embodies it. In light of the industrial disparities between Western nations and resistance groups in both the wars of decolonization and the War on Terror, this distinction between the laborer and the bombmaker is parallel to the motivational heuristic, in which one's own (or members of an in-group) reasons for an action can be explained by circumstances and environment, whereas others (or members of an out-group) are explained by inherent characteristics. ${ }^{36}$ This demonstrates an epistemic bias on the part of the theorist. Thus neither IHL nor just war theory entirely solves the ambiguity between non-combatant status as a role or identity.

\section{Colonialism as analogy, colonialism as context}

Focusing on the colonial context allows us to critically interrogate both reinterpretations of direct participation in hostilities as well as the tension between role and identity in just war theory. Colonial vigilante and 'counterterrorist' groups, like the OAS in Algeria and the Selous Scouts in Rhodesia, armed themselves to violently repress indigenous people. IHL makes allowances for targeting members of nonstate forces, so the paramilitary or vigilante groups organized by settlers would already be legitimate targets - just as modern terrorists are. Recent work critically reassessing non-combatant immunity and direct participation in the context of the War on Terror, though, looks beyond terrorist fighters to the civilians that (in an expansive sense) support them. Colonial settlers who do not take up arms may be analogous to these civilians; both can be theorized as engaging in aggression because of the roles they play in supporting state and/or non-state violence. In this section, I develop a theoretical account that treats colonial settlers as aggressors.

\footnotetext{
${ }^{34}$ Although just war uses the munitions factory worker as an example of double effect, some read IHL as permitting targeting the worker as a direct participant in hostilities. That the munitions worker is a contentious case, while the terrorist bombmaker is not, is sufficient to demonstrate my point.

${ }^{35}$ For some theorists, this is because the terrorist is an unlawful combatant and thus is not entitled to the protections that combatants are (cf. Jensen 2011). If he is an unlawful combatant, then he may be subject at any time to apprehension and prosecution for engaging in violence - although Jensen (among others) treats the terrorist as not only prosecutable but also subject to targeted killing at any time, which potentially endangers bystander civilians who rightly believe they are not in the theater of war. For more on the 'terrorist at a wedding' problem, see Van Engeland 2011.

${ }^{36}$ On the problems heuristics pose for scholars of international relations, see Jervis 1976, chap. 3. For the problem of circumstances vs. identities as explanations for action, see Mercer 1996, chap. 2.
} 
In the subsequent section, I demonstrate how, even in this expansive reading of settlers' roles, they still cannot be justly targeted, and why that challenges the expanded notions of legitimate targets proposed by Gross, Jensen, and Meisels, among others.

Settler colonialism is fundamentally a way of occupying and claiming sovereignty over territory. ${ }^{37}$ It is different than military occupation (and thus not necessarily best understood through international law governing occupation) for multiple reasons, one of which is that its aims are necessarily permanent. Military occupation can be (assumed to be) temporary, a function of military necessity in combat. Settler colonialism, on the other hand, is aggression because it seeks to assert sovereignty over territory. Furthermore, it is aggression because it is supported by the threat of violence, either from a formal state security apparatus or from looser, paramilitary groups. These are certainly sufficient jus ad bellum grounds. If we understand aggression as including assertions of sovereignty against and over others, and individuals as agents of those assertions, it may be plausible that settlers are directly participating in aggression. The ambiguity between whether combatant and non-combatant are defined by role or identity is particularly problematic in the case of settlers in colonial situations; settlers are civilians by identity, but the performance of the role in society they choose for themselves is markedly different than that of ordinary civilians. ${ }^{38}$ A settler is not necessarily directly participating in violence, but by his presence he implements the loss of territorial integrity and political sovereignty implied by colonialism. His identity as a 'civilian' is still the same as that of his fellow countrymen in the metropole, but his role is very different. Role, then, is also highly context specific.

The denial of political sovereignty to the indigenous population and the violation of their previous territorial integrity - the colonial system is an extension of invasion and occupation - makes identifying aggression more difficult. Although that previous territorial integrity may not have been recognized as itself 'sovereign' since sovereignty was often theorized against its assumed absence outside of Europe ${ }^{39}$ the concept of sovereignty implies a boundary which defines both an 'outside' and 'inside'. European state sovereignty must carry the possibility of an 'outside', which is where I locate an indigenous population's previous territorial integrity rather than consigning them to terra nullius.

According to Walzer, one gives up immunity from being targeted when one takes up arms - but regains immunity when one no longer effectively bears arms (whether due to injury or a cessation of one's duties). This is important - while Walzer defines soldiers as a class of people, their identification as combatants is based on action, or one's role in violence and aggression, not simply one's identity. Combatant status is dynamic.

Non-combatant, then, also may not be considered an 'identity', but a 'role'. Her role is not to be involved in committing violence or aggression during war. When

\footnotetext{
${ }^{37}$ Ford 2010, 4.

${ }^{38}$ Positing a distinction between identity and role implicitly rejects a performative definition of identity, that 'identity' is forged through social interaction to create a place in society for the individual or group. I use 'identity' as an in-born defining characteristic of an individual or group because that best captures the way many just war theorists treat civilians. Role, on the other hand, defines a person or group by their actions, thus capturing the problem of performativity.

${ }^{39}$ Anghie 2005, Benton 2009.
} 
working in a tank factory, her identity is the same but her role has changed. This change in role does not then justify targeting her (the tank factory must still remain the target), but now her death may be excused by the doctrine of double effect. 'The standards of permissibility rest on the rights of individuals, but they are not precisely defined by those rights' ${ }^{40}$ Context dictates the legitimacy of targeting in an approach that is not defined through rights-based arguments.

If defensive war is against a force that denies a people's territorial integrity and their political sovereignty, it is not immediately clear how the aforementioned categories may best be applied to the colonial situation. First-generation settlers are actively engaged in the denial of these two rights to indigenous peoples. But the settler herself is not necessarily the source of violence that enforces this situation. Certainly she is the rhetorical locus - settler 'lobbies' claiming to speak for the settlers often demand harsh, violent repression aimed at indigenous people, and politicians speak of needing to protect their people (the settlers) in the colonized land. Martha Crenshaw notes

Measures that would have provided the vast majority of Algeria's inhabitants (to most of whom even citizenship was denied) with anything approaching a state of equality, freedom, or prosperity - hence any stake in French Algeria were vigorously suppressed by the powerful settler lobby that largely controlled Algerian policy formulated by the national assembly in Paris. ${ }^{41}$

Political action is very different in colonially occupied territories, even when the metropole is a democratic state. In a democracy those who dissent may be waiting for the next election - as Aristotle frames it, to rule and be ruled in turn. And there are many potential forms of dissent in a democracy as well, so that failure to participate in one particular protest action or series of actions cannot be a gauge of opinion. In colonialism on the other hand, there is no political overhaul of indigenous rights plausibly in sight, so there is a much stronger case that those who stay are materially supporting or 'direct participants' in occupation, which may be understood as a form of aggression.

Not all settlers participate in violence against indigenous peoples or agree with the demands of the 'settler lobby' and it would be remiss to conclude from such representation that the settler as an identity is necessarily violent, thus relinquishing his immunity from attack. To do so would be to assign collective responsibility or collective guilt for the violence carried out against indigenous peoples.

Collective responsibility, though, implies collective identity - and as argued above, combatant and non-combatant categories are roles, not immutable identities. The question of direct participation looms large because even when the settler does not carry out violence herself, the role played by settlers is non-military aggressor against the territorial integrity and political authority of the indigenous community - an on-going violation, not simply something in the past. The question of collective guilt is more straight-forward. Guilt (as opposed to direct participation) is not limited in duration; it is a judgment rendered at some point, with

\footnotetext{
${ }^{40}$ Walzer 2000, 143.

${ }^{41}$ Crenshaw 1994, 479.
} 
punishment held out as the looming sanction. Punishment is not considered a legitimate end in contemporary just war theory ${ }^{42}$ - so targeting settlers in order to punish them for their participation in colonialism cannot be justified. Targeting must be done on the basis of some threat posed (including via a causal chain) and is thus anticipatory or reactive, whereas punishment is retributive.

Moving away from collective guilt and collective responsibility, it is helpful to think of two alternatives: collective ends and collective aggression. Seumas Miller argues that ends are collective when 'their realization requires a large number of different individual persons to perform distinct tasks in the service of a common end; indeed, to occupy a variety of different institutional roles in the service of a common end. There are planners, administrators, enforcers (combatants), leaders, and so on, engaged in a collective project'. ${ }^{43}$ Collective ends, in this way, are a way of thinking broadly about participation - but focusing on the enabling aspect of participation, contra the ICRC's interpretive guidance that limits direct participation to one causal step from violence. This is directly analogous to Gross's proposal to understand broad swathes of civilians and civilian infrastructure as implicated in terrorist violence because of the indirect support terrorist networks draw upon. ${ }^{44}$

While collective ends, as defined by Miller, reference the variety of distinct functions and tasks needed to achieve ends, collective aggression (as I propose it) recognizes the quantity of actors needed. Focusing on collective ends with reference to the colonial context directs our attention to the colonial bureaucracy, security apparatus, and so on, while collective aggression directs our attention to the need for bodies to occupy space. The settler colonial state needs bureaucrats, but more than anything, it needs settlers.

For the uncolonized, it is easy to look across the world and see two kinds of people: civilian and soldier. The civilian does not take up arms; the soldier does, so the civilian is referred to as a non-combatant and the soldier a combatant. ${ }^{45}$ These categories may not be sufficient for examining the colonized world. Indigenous people and settlers perform very different roles. Are they both performing the role of 'noncombatant'? Or are agents of colonialism always engaged in a threat of force?

From a Lockean perspective, liberal society is founded on the threat of force. That force is defined as self-defense. While numerous postcolonial thinkers emphasize how economic demands against other states come to be made in the name of self-defense ${ }^{46}$ it is more productive for present purposes to think about states' claims of self-defense when acting to defend their citizens dispersed across the globe through colonialism or military adventurism. ${ }^{47}$ When settlers are targeted, states with whom the settlers are affiliated treat the settlers' supposed civilian identity as equivalent to non-combatant status. By not acknowledging settler

\footnotetext{
${ }^{42} \mathrm{McKeogh} 2002$.

${ }^{43}$ Miller 2009, 71.

${ }^{44}$ See, for example, Gross 2010, 162.

${ }^{45}$ This explanation does not capture the nuances of the categories, but it does capture the general spirit of the dichotomy.

${ }^{46}$ E.g. Asad 2007, Orford 2003.

${ }^{47}$ This is distinct from Finnemore's (1999) category of intervention to protect co-nationals/co-ethnics what I am discussing are the actions of states to protect citizen-settlers, not co-ethnics who live across state boundaries.
} 
colonialism as ongoing aggression against indigenous populations it is easy to obfuscate any role the victim played in collective ends or collective aggression. Thus, the legacy of colonialism can be shown to affect considerations even of the combatant/non-combatant distinction - we flatten the political terrain and postulate that all who are not actively fighting are non-combatants, rather than exploring how colonial violence extended beyond open war. Again, it is easier to theorize exceptions for 'others' than to compromise the immunities of people like ourselves.

It is important to emphasize that this problematizing settlers as non-combatants does not condone targeting based solely on political affiliation. Walzer warns that 'ordinary citizens, not engaged in political harming - that is, in administering or enforcing laws thought to be unjust - are immune from attack whether or not they support those laws, ${ }^{48}$ In some scenarios, where insurgencies and terrorist networks have political wings, this question of membership becomes especially fraught. ${ }^{49}$ The settler's allegiance to the mother country is freedom of conscience for which she may not be attacked. However, this allegiance paired with her violation of the indigenous community's territorial integrity becomes a different question than freedom of conscience. The presence of the settler qua settler, rather than as a co-equal citizen, is an ongoing violation against the territorial integrity and political sovereignty of the indigenous that parallels military invasion. Although colonial domination by definition included significant quotidian violence, this is not always recognized as 'violence' by mainstream just war or IR theory. ${ }^{50}$ However, in just war theory every violation of territorial integrity and political sovereignty is aggression, ${ }^{51}$ so the failure to recognize the settler's role as violent need not in itself be an impediment to liability. Is it possible to forgo one's privileges as a settler without leaving the territory and returning to the mother country? Some people choose to abdicate advantages conferred on them by their status as citizens of the colonizing power; living in integrated communities, often away from the centers of colonial administration that would have enforced unequal citizenship. By doing so they accept, and might be accepted by, the indigenous population as co-equal citizens with a legitimate home in the region. However, many postwar anti-colonial theorists argued it was not possible for settlers to simply refuse their privileges and live as equals. ${ }^{52}$ But there are different ways of using one's advantages as a settler. Purchasing land from an indigenous person signifies recognition that the land was theirs to sell. On the other hand, claiming the land oneself and then demanding the colonial government recognize one's ownership, or buying land expropriated by the government from indigenous people, signifies that one does not recognize the indigenous as having rights to the land. Taking this paradigm of mutual recognition, it becomes possible to engage

\footnotetext{
${ }^{48}$ Walzer 2000, 200.

${ }^{49}$ Jensen first argues (p. 86) that membership alone justifies targeting. He backtracks shortly thereafter (p. 89), claiming that political wings of terrorist organizations would be immune from targeting, but provides no robust justification for why his earlier logic does not implicate political wings, so it remains an ad hoc distinction.

${ }^{50}$ Baron et al. 2019.

${ }^{51}$ Walzer 2000, 52.

${ }^{52}$ The classic example is Albert Memmi (1957) 1991.
} 
claims of settler 'culpability' more critically, rather than asserting an all-or-nothing position.

First-generation settlers certainly make the active choice to violate an indigenous population's political sovereignty and territorial integrity. But can the same be said of subsequent generations? Does being born in a region free these following generations of choice, as their land of birth is their 'indigenous' land? Upon reaching maturity, they decide whether or not to accept their role as colonizer - simply 'doing nothing' is, in fact, a choice on their part to continue the violation of territorial integrity and political sovereignty of the indigenous population. Certainly some choice is mitigated; when they are children, they are subject to the wills of their parents, and so cannot be expected to accept or repudiate their roles as colonizers.

The colonial context makes the settler distinct from ordinary civilians. The settler is defined by a violation of territorial integrity and political sovereignty - thus participating in aggression. The ability to exit the colonial context and not carry the designation settler with him marks 'settler' as a role, rather than an inherent identity (in contrast to the terrorist who cannot leave the theater of war and become a civilian). The settler who recognizes the indigenous right to a nation is no longer a settler, but (potentially) a co-national. ${ }^{53}$ Thus, in the colonial context, the settler occupies an ambiguous position with regard to his role in aggression.

\section{Targeting settlers as aggressors? Dead ends and refutations}

My theoretical exploration leads me to argue that while the aggression identified above might make the settler a legitimate target, targeting the settler in a discriminate manner is ultimately impossible - thus foreclosing this possibility. Paradoxically, this is a very context-specific question. In the just war tradition, context dictates the legitimacy of targeting; an armed soldier is a legitimate target, but that same soldier in a different context (if wounded, surrendering or outside of a theater of war) is no longer a legitimate target.

If we take the colonization of territory as the continued violation of the indigenous community's territorial integrity, and thus an instance of aggression, then independence movements engaged in settler targeting are reacting against a 'specific instance of unjust aggression, perpetrated against one's own people or an innocent third party'. ${ }^{54}$ If the attacks are directed at agents of these aggressions as part of a declared war to end colonial occupation (that was declared as a last resort), rather than to simply satiate a desire for revenge against oppressors (thus embodying right intention), and the organization carrying out attacks has a legitimate monopoly on violence within the resistance movement, the criteria for jus ad bellum have been met.

A difficulty arises when identifying 'agents' of the aggression. Traditionally, the combatant/non-combatant divide is easily recognizable as the line between those

\footnotetext{
${ }^{53}$ The settler is different from migrants and undocumented immigrants. Migrants arrive expecting to adhere to the laws and government of the local people. Undocumented immigrants do not violate the territorial integrity of a country because they do not claim ownership of the territory in which they live, nor do they contest its political sovereignty.

${ }^{54}$ Elshtain 2004, 57.
} 
who may be held responsible and those who cannot. As noted earlier, however, the colonial situation presents a unique challenge to the questions of responsibility and vulnerability.

As the settler is personally responsible for her role, she must be given the option of righting her violation of territorial integrity and political sovereignty. She can recognize the rights of local people by either returning to her indigenous country or accepting the establishment of a new, representative political authority. In the first case, she renounces her identity as a settler by repatriation, while in the second case she does so by seeking citizenship in the new nation. In both cases she repudiates her role as settler. Her third option, which does not recognize the rights of the indigenous population, is to 'do nothing', to retain her role as settler.

The settler must be given the option of taking part in the nation that rebelling indigenous people wish to create. To found a state based on settler-exclusion would be to confuse the offense of the settler. Her offense is not her physical presence per se, but that her presence coupled with her allegiance to the mother country or settler government denies political sovereignty and territorial integrity to the indigenous population. The settler can seek citizenship in the new nation. If she rejects that, she is not only rejecting a vague notion of citizenship in a new nation but also the right of the people to claim their territorial integrity and political authority. Giving settlers the option to leave the colony or join the independence movement allows them to move toward a role as co-citizen. The question of integrating former colonial settlers is of course fraught - Zimbabwe's post-independence land reforms are the paradigmatic case of how such integration can fail, while South Africa has been much more successful. But from a normative perspective it is reasonable to assume some possibility of postcolonial reconciliation and integration. ${ }^{55}$

Here I return to two ways other theorists have interrogated the category of noncombatant: the first, employed by some just war theorists ${ }^{56}$ is to propose that innocence qua harmless is a poor standard for whether someone is a legitimate target, and instead ask whether someone is innocent qua blameless. This view is potentially much more expansive. The second way is to ask whether someone might be understood as a 'direct participant in hostilities', using the language of Additional Protocol 1.

The framework of innocent qua blameless has been used to ask about the ethics of democratic citizenship in war - can democratic publics be considered liable for the actions of their governments? Should democratic publics be targeted in response to the military actions of their government? It is tempting to import this line of reasoning to the colonial realm, where it might have more salience than for democratic governments. Sparrow (2005) notes that a central stumbling block for such questions is the problem of institutions, especially elections. Elections simply aren't good barometers of public support for various individual policies, let alone questions of grand strategy or imperial domination. Various other forms of protest are possible in a democratic state, and it would be unjust to assert that those who were not participating in specific protests were in fact

\footnotetext{
${ }^{55}$ The problem of postcolonial reconciliation and integration, especially the question of who owes what to whom after colonialism, is ultimately beyond the scope of this essay but is treated masterfully in Lu, 2018 .

${ }^{56}$ Primoratz 2002, Blahuta 2013.
} 
consenting to politics-as-usual. But as I argued above, the political possibilities in the colonial setting are radically reduced compared to (an idealized) democratic form of representation. If there are elections, settler lobbies and politicians conspire to foreclose any democratic solution to the oppression of indigenous people. The colonial context thus simplifies what is sometimes referred to as the "epistemic problem' - can we assume that civilians and/or soldiers are capable of making informed decisions about the justness of their cause ?7 $^{57}$ Those who continue to live in the colony as settlers, it can be inferred, are neither blameless for nor (reasonably) ignorant of the policies which protect and privilege them.

Importantly, though, arguments in favor of narrowing civilian immunity with regard to democratic publics rely on a logic of punishment rather than one of participation and threat - blame and blamelessness are moral evaluations related to guilt. Punishment, however, is not considered a legitimate aim in either modern just war or IHL. An important aspect of civilian immunity is that civilians are legally culpable for offenses for which combatants may not be. By treating civilian offenses as targetable offenses, rather than prosecutable offenses, such arguments simply strip civilians of wartime protections. Thus, if colonial occupation is an offense meriting punishment it does not make the settler liable to lethal harm.

Allowing for settlers to be targeted is markedly different than allowing for the targeting of civilians in conventional conflicts. Civilians that remain in their respective country are not individually violating the territorial integrity and political sovereignty of an opposing nation. If they encourage their governments to do so, that is an expression of their political will, and they cannot be targeted for it. Settlers, on the other hand, are actively violating the territorial integrity and political sovereignty of another. Such an active choice must imply individual responsibility on the part of the settler. Because the settler's role is not recognized by many as violent, this appears different than targeting traditional combatants. The combatant actively threatens violence - he actively bears arms, and this puts the physical well-being of others in danger. It is here that the question of direct participation in hostilities is both helpful and opaque. Interpreters of AP I generally are in agreement that 'direct participation in hostilities' does not mean each participant is individually threatening or engaged in violence - the ICRC's interpretive guidance allows for targeting an actor who is separate from violence by one causal step. ${ }^{58}$

Direct participation is also distinguished by the ICRC from 'indirect' participation - which includes action that 'contributes to the general war effort of a party, but does not directly cause harm and, therefore, does not lead to a loss of protection against direct attack ${ }^{59}$ Political and administrative support would fall into this category. Just war theorists respect a similar distinction, although Walzer's formulation is broader: 'The relevant distinction is not between those who work for the war effort and those who do not, but between those who make what soldiers need to fight and those who make what they need to live, like all the rest of

\footnotetext{
${ }^{57}$ For an overview of the (analytic) literature on the epistemic problem as applied to civilians, see Steinhoff 2010.

${ }^{58}$ Akande 2010.

${ }^{59}$ Melzer 2009.
} 
us' ${ }^{60,61}$ It would seem, then, that perhaps settlers (and the civilian allies of modern terrorists) are simply engaged in 'indirect participation'. But the most important distinction between the ICRC's guidance and just war is the former's focus on hostilities as violence, and the latter's focus on aggression. Some settlers may be one causal step from violence. But re-reading the question of direct participation in relation to aggression, rather than specifically violence, allows us to consider the specific harm in which the settler is engaged. Some settlers could thus be considered legitimate targets.

The greatest danger of targeting the settler, though, lies in the problem of distinguishability. Here the analogy to Gross (2010) and Jensen (2011) is most direct, as their defenses of expanded civilian culpability are predicated on distinguishing between civilians. While not impossible, it would be difficult to know which members of the colonizing country were fulfilling the role of the settler, and which not. Public spaces frequented by non-indigenous people often host both those that accept the role of settler as well as those that reject it - simply placing a bomb in a café or on a bus would be indiscriminate targeting, and by no means just. Families in which some adult household members cannot express disagreement with the settler role could experience unjust casualties if adult family members are targeted - and any children killed in such an attack would be by their very nature unjustly killed. Intelligence agents could infiltrate meetings about the future role of colonizers in the territory and identify individuals who favor the continuation of the colonial status quo, and then those individuals could be specifically targeted. However, this is assassination because it targets a series of discrete individuals, whereas direct targeting threatens a class of people or those who can be observed directly participating in hostilities. The ethics, laws, and norms concerning assassination are different than for direct targeting. ${ }^{62}$

If the settler were considered a legitimate target, then the doctrine of double effect would be applicable when non-combatant lives are threatened. But this doctrine does not simply excuse collateral deaths; it holds attackers to a stringent standard regarding the possibility of non-combatant deaths. One must take positive steps to minimize non-combatant deaths, and the overall effect of the attack must be to further legitimate strategic goals, not simply to kill more of the enemy. As agents of occupation, settlers could in these limited instances be considered legitimate strategic objectives - however, they would only take on this mantle in reference to their participation in the colonization of other people's lands. Attacks on settlers would have to be to induce them to abandon their roles and encourage the government of the mother country to change its policy of colonization. Defining ethnic cleansing or the removal of anyone from a particular group identified as 'objective enemies' as a strategic objective is clearly illegitimate.

Double effect, though, requires the maintenance of 'the highest possible standards of care' when determining potential non-combatant deaths, and may still

\footnotetext{
${ }^{60}$ Walzer 2000, 146.

${ }^{61}$ It should be noted that Gross's (2010) proposal of 'associated targets' that include civilian infrastructure like banks and schools is the absolute rejection of Walzer's distinction.

${ }^{62}$ Cf., eds. Finkelstein et al. 2012.
} 
prove disproportionate to the value of a target. ${ }^{63}$ Double effect in the just war tradition must be understood as limiting what one can do, rather than merely permitting more - the relevant contrasts are against both absolute prohibition on civilian death and the permissiveness of 'necessity'. A low level of distinguishability between actors renders absurd arguments that one has upheld the 'highest possible standards of care' in a situation - even if the target were, as in Meisels' proposed case of the 'terrorist mastermind', plausibly legitimate. The logistical barriers to a discriminatory settler-targeting would make it infeasible in all but the most exceptional cases.

The problem of distinguishability would thus exist for all attempts to claim civilian complicity with aggression as forfeiting non-combatant immunity. While I have not examined specific cases of whether civilian complicity with more recent terrorist aggression might be grounds for jus in bello, it is clear from my analysis that the logic of the more substantial claims I outlined in the Introduction about forfeiting non-combatant immunity for such complicity cannot be sustained.

\section{Conclusion}

Recent work in just war theory and IHL has proposed significantly eroding noncombatant immunity on the basis of a broad understanding of civilian complicity in violence. Using the role of the colonial settler for theoretical exploration, this essay demonstrates the significant shortcomings of such a critical reassessment of civilian immunity. It is on the basis of discrimination, the inability to reliably distinguish between varying levels of liability, that this possibility must be rejected. Furthermore, historical analogies help us critically engage our own context, and remind us that contemporary crises are rarely as unique as we may imagine.

By introducing the problem of distinguishability as a barrier to civilian culpability, I identify an unacknowledged problem in the work of Gross (2010) and other theorists who posit that civilian complicity with terrorist organizations forfeits or diminishes non-combatant immunity. Furthermore, they are ultimately either promoting ends that cannot be justified through just war theory (such as punishment), or fudging differences between targeted killing and direct targeting in order to morally justify tactics that remain normatively dubious, even if they are employed with increasing frequency. ${ }^{64}$ This does not mean that nothing can be done to such targets. Rather, it calls for prosecution or confinement. It is not impossible to identify such figures; however, the process of identification and distinction ultimately calls for a different set of actions than a narrowing of civilian immunity.

The ambiguity of role and identity in just war theory proves very problematic when dealing with what was a common target of terrorism, the settler, who may be identified either through his role or his identity. I demonstrate that this ambiguity makes it possible to recognize the colonial settler as aggressor, analogous to the ways in which civilians have recently been accused of culpability for terrorist violence. From a theoretical perspective, exploring the tension between role and identity in just war theory and some IHL, and how one can elide into the other,

\footnotetext{
${ }^{63}$ Walzer 2000, 156.

${ }^{64}$ Carpenter 2011.
} 
helps us to think critically about the ways in which claims of culpability may expand to include broad swathes of the population. Maintaining a narrow understanding of direct participation or effectively bearing arms can help prevent people's identities being classified as threatening, as US drone policy has done by treating all non-child and non-elderly male civilians as themselves suspect.

Politically, by reversing the gun sights and questioning the immunity of Western civilians, this essay works to undermine the instrumental use of just war to legitimate the killing, if not always direct targeting, of non-Western civilians. Claiming just war as a normative language about violence that may challenge Western states' assertions of necessity and right in contemporary conflicts is a larger project, of which this essay is an important first step. In particular, this essay has implications for thinking critically about civilian infrastructure as well as the revisionist analytical approach to just war theory.

It is worth returning to Gross' (2015) argument about sliding scales, indirect participation, and associated targets. Even though settler colonists are not, in my formulation, legitimate targets, it is possible that infrastructure or institutions associated with settler colonialism might be legitimate targets. When taking the violence of colonialism seriously, the role of land redistribution/homestead offices and other institutions traditionally understood as related to 'civilian life' becomes an important question. In some cases these were government agencies, like the General Land Office in late $19^{\text {th }}$ century USA which provided Western 'homesteads' made up of unconquered Indian land to White settlers (conflicts over these homesteads led to the late $19^{\text {th }}$ century 'Indian Wars' that redirected a triumphant Union army westward), while in other cases they were chartered corporations like the Hudson Bay Company in Canada. ${ }^{65}$ As with other aspects of settler colonialism the disappearance of de jure colonial rule did not make these problems disappear. Late $20^{\text {th }}$ century and early $21^{\text {st }}$ century Maoist guerrillas targeted similar institutions: Sendero Luminoso in Peru and the Communist Party of Nepal (Maoist Centre) both targeted records offices in order to 'erase' the institutionalization of class oppression. ${ }^{66}$ There is a prima facie plausibility that such institutions would not raise the same distinguishability/discrimination problems that settler targeting ultimately cannot overcome - an office dedicated to seizing indigenous land and redistributing it to settlers is engaged in colonial violence, full stop. Whether such offices should be treated as akin to a munitions factory, in which workers killed in an attack on the factory are legitimate collateral damage, or whether guerrillas would need to forcibly evacuate such offices before destroying them, is actually a difficult question. Future work on the liability of institutions and infrastructure needs to grapple with these problems seriously.

This essay also raises a broader methodological challenge. I start from the premise that a postcolonial approach to ethics and war can uncover and challenge constitutive concepts and assumptions. Analytic/revisionist just war theorists have also probed the problem of 'morally liable non-combatants' ${ }^{367}$ and our conclusions about targeting overlap. But in adopting Nagel's 'view from nowhere' the

\footnotetext{
${ }^{65}$ Benjamin Nolan and Adam Dahl brought these two particular agencies to my attention.

${ }^{66}$ Marks and Palmer 2005.

${ }^{67}$ McMahan 2009.
} 
revisionists miss an opportunity to critically probe contexts to uncover the academy's own epistemic biases and blindspots and overlook deep structural oppression. The ability to recognize structural issues and epistemic biases allows one to potentially utilize just war in broader conversations about justice, rather than treating it as a non-ideal ethical system only relevant to narrow questions. ${ }^{68}$ Finally, several revisionists disavow any engagement with IHL, instead claiming to focus on the 'deep morality of war'. My argument demonstrates that a postcolonial approach can combine the deeper moral examination of complicity and responsibility the revisionists aspire to with an engaged critique of IHL. These need not be separate endeavors, and indeed separating them simply undermines IHL. For if IHL is morally indefensible, simply pragmatic or a political necessity, then cynical political leaders can declare themselves not bound by IHL, claiming instead to obey a 'deeper' morality of war - as demonstrated by the eagerness with which many political leaders during the War on Terror embraced the neo-imperial formulations of just war.

\section{References}

Akande, Dapo. 2010. “Clearing the Fog of War? The ICRC's Interpretive Guidance on Direct Participation in Hostilities." International \& Comparative Law Quarterly 59 (1): 180-92.

Anghie, Antony. 2005. Imperialism, Sovereignty, and the Making of International Law. Cambridge: Cambridge University Press.

Asad, Talal. 2007. On Suicide Bombing (The Wellek Library Lectures). New York: Columbia University Press.

Baron, Ilan Zvi, Jonathan Havercroft Isaac Kamola, Jonneke Koomen, Justin, Murphy, and Alex, Prichard. 2019. "Liberal Pacification and the Phenomenology of Violence." International Studies Quarterly 63 (1): 199-212.

Benton, Lauren. 2009. A Search for Sovereignty: Law and Geography in European Empires, 1400-1900. Cambridge: Cambridge University Press.

Blahuta, Jason P. 2013. "Re-Evaluating the status of Noncombatants in Just War Theory and Terrorism." In Routledge Handbook of Ethics and War: Just War Theory in the Twenty First Century, edited by Fritz Allhof et al., 253-64. New York: Routledge.

Carpenter, Charli. 2011. "Fighting the Laws of War," Foreign Affairs. Accessed 30 March 2016. https:// www.foreignaffairs.com/reviews/review-essay/2011-03-01/fighting-laws-war.

Crawford, Neta C. 2013. "Bugsplat: US Standing Rules of Engagement, International Humanitarian Law, Military Necessity, and Noncombatant Immunity." In Just War: Authority, Tradition, and Practice, edited by Anthony F. Lang et al., 231-49. Washington, DC: Georgetown University Press.

Crenshaw, Martha. 1994. "The Effectiveness of Terrorism in the Algerian War." In Terrorism in Context, edited by Martha Crenshaw, 473-513. University Park, PA: The Pennsylvania State University Press.

Deane, Herbert. 1966. The Political and Social Ideas of Saint Augustine. New York, Columbia University Press.

Dill, Janina. 2015. Legitimate Targets? Social Construction, International Law, and US Bombing. Cambridge: Cambridge University Press.

Dinstein, Yoram. 2004. The Conduct of Hostilities under the Law of Armed Conflict. Cambridge: Cambridge University Press.

Elshtain, Jean Bethke. 2004. Just War against Terrorism. New York: Vintage Books.

Elshtain, Jean Bethke. 2007. “Terrorism.” In The Price of Peace, edited by Charles Reed, and David Ryall, 118-35. Cambridge: Cambridge University Press.

\footnotetext{
${ }^{68} \mathrm{My}$ argument is thus also critical of the Augustinian account of the just war as solely a remedial tool (Deane 1966). Rather, I posit that just war guided by postcolonial concept critique provides insight into structural injustice. However, a thorough engagement with this aspect of the tradition is beyond the scope of this paper.
} 
Etzioni, Amitai. 2016. “Should Israel Flatten Beirut to Destroy Hezbollah's Missiles?” Haaretz. Available at: http://www.haaretz.com/opinion/.premium-1.703486. Accessed February 17, 2016.

Finkelstein, Claire. et al. eds. 2012. Targeted Killings: Law and Morality in an Asymmetrical World. Cambridge: Cambridge University Press.

Finnemore, Martha. 1999. The Purpose of Intervention: Changing Beliefs about the Use of Force. Ithaca, New York: Cornell University Press.

Ford, Lisa. 2010. Settler Sovereignty: Jurisdiction and Indigenous People in America and Australia, 17881836. Cambridge: Harvard University Press.

Gross, Michael L. 2010. Moral Dilemmas of Modern War: Torture, Assassination, and Blackmail in an Age of Asymmetric Conflict. Cambridge: Cambridge University Press.

Gross, Michael L. 2015. The Ethics of Insurgency: A Critical Guide to Just Guerrilla Warfare. Cambridge: Cambridge University Press.

International Committee of the Red Cross (ICRC), Protocol Additional to the Geneva Conventions of 12 August 1949, and relating to the Protection of Victims of International Armed Conflicts (Protocol I), 8 June 1977, 1125 UNTS 3, available at: https://www.refworld.org/docid/3ae6b36b4.html [accessed 19 September 2020]

Jensen, Eric Talbot. 2011. “Direct Participation in Hostilities: A Concept Broad Enough for Today's Targeting Decisions." In New Battlefields, Old Laws: Critical Debates on Asymmetric Warfare, edited by William C. Banks, 85-105. New York: Columbia University Press.

Jervis, Robert. 1976. Perception and Misperception in International Politics. Princeton: Princeton University Press.

Johnson, James Turner. 1999. Morality and Contemporary Warfare. New Haven: Yale University Press.

Johnson, James Turner. 2005. The War to Oust Saddam Hussein: Just War and the New Face of Conflict. Washington, DC: Rowman and Littlefield Publishers.

Kasher, Amos, and Asa Yadlin. 2005. "Military Ethics and Fighting of Terror: An Israeli Perspective." Journal of Military Ethics 4 (1): 3-32.

Kinsella, Helen M. 2012. The Image before the Weapon: A Critical History of the Distinction Between the Combatant and Civilian. Ithaca: Cornell University Press.

Lazar, Seth. 2015. Sparing Civilians. Oxford University Press.

Lu, Catherine. 2018. Justice and Reconciliation in World Politics. Cambridge: Cambridge University Press. Mamdani, Mahmood. 1996. Citizen and Subject: Contemporary Africa and the Legacy of Late Colonialism. Princeton: Princeton University Press.

Marks, Thomas A., and David Scott Palmer. 2005. "Radical Maoist Insurgents and Terrorist Tactics: Comparing Peru and Nepal.” Low Intensity Conflict \& Law Enforcement 13 (2): 91-116.

McKeogh, Colm. 2002. Innocent Civilians: The Morality of Killing in War. New York: Palgrave Macmillan.

McMahan, Jeff. 2009. Killing in War. Oxford: Oxford Clarendon Press.

Meisels, Tamar. 2008. The Trouble with Terror: Liberty, Security, and the Responses to Terrorism. Cambridge: Cambridge University Press.

Melzer, Nils. 2009. "Interpretive Guidance on the Notion of Direct Participation in Hostilities under International Humanitarian Law," Available online https://www.icrc.org/eng/assets/files/other/icrc-0020990.pdf. Accessed March 3, 2016.

Memmi, Albert. 1991. The Colonizer and the Colonized. Boston: Beacon Press. Expanded edition.

Mercer, Jonathan. 1996. Reputation and International Politics. Ithaca: Cornell University Press.

Miller, Seumas. 2009. Terrorism and Counter-Terrorism: Ethics and Liberal Democracy. Malden: Wiley-Blackwell.

Nablusi, Karma. 1999. "Evolving of Civilians and Belligerents: 100 Years after the Hague Peace Conferences." In Civilians in War, edited by Simon Chesterman, 9-24. Boulder, CO: Lynne Rienner Publishers.

O'Callaghan, Ronan. 2015. Walzer, Just War, and Iraq: Ethics as Response. New York: Routledge.

Orend, Brian. 2006. The Morality of War. Peterborough, Toronto: Broadview Press.

Orford, Anne. 2003. Reading Humanitarian Intervention: Human Rights and the Use of Force in International Law. Cambridge: Cambridge University Press.

Primoratz, Igor. 2002. “Michael Walzer's Just War Theory: Some Issues of Responsibility.” Ethical Theory and Moral Practice 5: 221-43.

Sparrow, Robert. 2005. "'Hands up Who Wants to Die?' Primoratz on Responsibility and Civilian Immunity in Wartime.” Ethical Theory and Moral Practice 8: 299-319. 
Steinhoff, Uwe. 2010. "Civilians and Soldiers." In Civilian Immunity in War, edited by Igor Primoratz, 4261. Oxford: Oxford University Press.

Sterba, James. 2003. “Terrorism and International Justice." In Terrorism and International Justice, edited by James P. Sterba. New York: Oxford University Press.

Tesón, Fernándo R. 2005. "Ending Tyranny in Iraq," in Ethics and International Affairs, Vol. 19.2, pp. 1-20. van Engeland, Anicee. 2011. Civilian or Combatant? A Challenge for the $21^{\text {st }}$ Century. Oxford: Oxford University Press.

Veracini, Lorenzo. 2016. "Introduction: Settler Colonialism as a Distinct Mode of Domination." In The Routledge Handbook of the History of Settler Colonialism, edited by Edward Cavanaugh and Lorenzo Veracini, 1-8. New York: Routledge.

Walzer, Michael. 2000. Just and Unjust Wars: A Moral Argument with Historical Illustrations, 3rd ed. New York: Basic Books.

Walzer, Michael. 2006. "War Fair.” The New Republic, available at: https://newrepublic.com/article/65551/ the-ethics-battle. Accessed February 20, 2016.

Zenko, Micah. 2013. "Reforming US Drone Strike Policies," Council on Foreign Relations, Council Special Report No. 65.

Cite this article: Mares, G. 2021. "Just war theory after colonialism and the war on terror: reexamining noncombatant immunity." International Theory 13, 483-505, doi:10.1017/S1752971920000482 